\title{
SELECTED PROCEEDINGS
}

\section{International Conference for Philosophy, Psychiatry and Psychology 26 - 29 June 2014, Golden Sands Resort, Bulgaria}

\section{LATENT BIPOLARITY IN UNIPOLAR DEPRESSION: EXPERIMENTAL FINDINGS, CONCEPTUAL ANALYSIS AND IMPLICATIONS FOR TREATMENT STRATEGIES}

Petya D. Terziivanova*, Svetlozar H. Haralanov

First Psychiatric Clinic, St Naum University Hospital of Neurology and Psychiatry, Medical University, Sofia, Bulgaria

\section{СКРЫТАЯ БИПОЛЯРНОСТЬ В УНИПОЛЯРНОЙ ДЕПРЕССИИ: ЭКСПЕРИМЕНТАЛЬНЫЕ ДАННЫЕ, КОНЦЕПТУАЛЬНЫЙ АНАЛИЗ И ПОСЛЕДСТВИЯ ДЛЯ СТРАТЕГИИ ЛЕЧЕНИЯ}

Петя Д. Терзииванова*, Светлозар Х. Хараланов Первая психиатрическая клиника Университетской больнищы неврологии и психиатрии имени Св. Наума, Медицинский университет, София, Болгария

\begin{abstract}
InTRODUCTION: Previous studies have suggested that the two opposite poles of psychomotor disturbances in unipolar depression (UD) - retardation and agitation - require different treatment strategies as the psychomotor overactivation requires an augmentation of the antidepressant therapy with mood stabilizers and/or atypical antipsychotics. Овлестіve: The aim of the present study was to objectively identify and measure the psychomotor disturbances in UD using differentiation between activity and reactivity. MATERIAL AND METHODS: An equilibriometric movement pattern analysis system that allows differentiation between psychomotor activity and reactivity was applied in 58 unipolar depressive patients and 76 healthy controls. Results: Compared to controls, the patients as a group were significantly slower in their psychomotor reactivity. However, the subsequent subgrouping according to the direction of deviation of their objective psychomotor parameters revealed a disinhibition of psychomotor activity and/or reactivity in about one half of them. Such a contradictory combination of clinically manifested depressive mood and subclinically detected manic-like psychomotor overactivation might be regarded as belonging to the bipolar spectrum, since it was admitted that manic psychomotor disinhibition in unipolar depressive patients uncovers a latent bipolarity. ConcLusion: Not only prototypical depressive inhibition, but also prototypical manic-like disinhibition may underlie clinically manifested UD. Since the combination between depressive mood and psychomotor overactivation multiplies the suicidal risk, we may presume that the timely detection of this combination at a subclinical level would contribute to an earlier and more effective suicidal prevention by an objectively-guided optimization of pharmacological treatment.
\end{abstract}

Key words: unipolar depression, cranio-corpo-graphy, psychomotor disturbances, bipolarity, suicidal prevention

Folia Medica 2014; 56(4): 282-288 Copyright (C) 2014 Medical University, Plovdiv

\section{РЕЗЮМЕ}

ВведЕниЕ: Предыдущие исследования показали, что два противоположных полюса психомоторных нарушении в униполярной депрессии (УД) - замедление и перемешивание - требуют разных стратегий лечения, так как психомоторная сверхактивация требует добавления стабилизаторов настроения и/или атипичных нейролептиков к антидепрессивной терапии. Цель: Целью настоящего исследования является объективная регистрация и измерение психомоторной активности и реактивности при УД. МАтЕРИАЛ и методы: Кранио-корпография как система, позволяющая дифференцировать психомоторную активность и реактивность, была применена в отношении 58 униполярных депрессивных пациентов и 76 здоровых людей. РезультАты и обсуждениЕ: По сравнению с контрольной группой, пациенты как группа были значительно медленнее в их психомоторной реактивности. Однако последующее субгруппирование в соответствии с направлением отклонения их объективных психомоторных параметров показали растормаживание психомоторной активности и/или реактивности примерно у половины из них. Такое противоречивое сочетание клинически проявленного депрессивного настроения и субклинически 
обнаруженная маниакально психомоторная сверхактивация может рассматриваться как принадлежащее к биполярному спектру, так как было признано, что маниакальная психомоторная расторможенность среди униполярных депрессивных пациентов указывает на скрытую биполярность. ЗАключениє: Не только прототипное депрессивное торможение, но и прототипная маниакальная расторможенность могут лежать в основе клинически проявляющейся УД. Посколько сочетание депрессивного настроения с психомоторной сверхактивацией увеличивает суицидальный риск, можно предположить, что своевременное субклиническое обнаружение этой комбинации будет способствовать более ранней и более эффективной суицидальной профилактике путём объективно-управляемой оптимизации фармакологического лечения.

Ключевые слова: униполярная депрессия, кранио-корпография, психомоторные нарушения, биполярность, суициидальная профилактика

Folia Medica 2014; 56(4): 282-288

(C) 2014 Bсе права защищены. Медицинский университет, Пловдив

\section{INTRODUCTION}

The lifetime prevalence of major depressive disorder is approximately $16 \% .^{1}$ In Europe nine out of a thousand people suffer from depression. ${ }^{2}$ Recurrent by nature, depression is associated with a great number of years of life lost due to disability and premature death. It is not surprising that the world-spread difficulties in clinical identification of depressive syndrome, the delays of psychiatric consultation and treatment initiation, as well as the poor management of patients are all expected to make depression the second leading cause of disability by the year $2020 .^{3}$

Clinical depression is a multidimensional psychiatric illness. It includes 4 main domains: negative affectivity (depressive mood), changes in cognitive functions (cognitive deficits), poor neurovegetative control (autonomic dysregulation) and psychomotor disturbances. Psychomotor disturbances are regarded as cardinal symptoms of depression. ${ }^{4-10}$ The latter encompass two opposite deviations from the norm - retardation and over-activation or agitation. In psychomotor retardation, the depressive mood corresponds to an overall reduction and slowness in volitional activity and emotional reactivity of the patient. Conversely, in psychomotor agitation, the depressive mood is associated with a raise in volitional activity and/or emotional reactivity.

According to its longitudinal course, the endogenous depression could be unipolar or bipolar. Recently, it was revealed that the treatment of unipolar and bipolar depression is very different if not conflicting. Hence, it is important to make distinction between these two types of depressive illness. The main problem is that the detection of bipolarity is complicated by the fact that in a half of cases the bipolar disorder manifests itself with a series of depressive episodes before the onset of the first manic, hypomanic or mixed episode. ${ }^{11}$ Therefore, a bipolar depression is often seen as "unipolar" and is incorrectly treated with antidepressant monotherapy. Such a medication could worsen the course of the illness. ${ }^{12-14}$ The presence of manic symptoms accompanying the current depressive episode tends to be associated with rapid cycling, increased suicidality and a greater incidence of substance abuse. ${ }^{15,16}$ It is well-known that the

Table 1. Descriptive statistics of unipolar depressive patients and healthy controls

\begin{tabular}{lccc}
\hline & $\begin{array}{c}\text { Unipolar Depression } \\
(\mathbf{n}=\mathbf{5 8})\end{array}$ & $\begin{array}{c}\text { Healthy Controls } \\
(\mathbf{n}=\mathbf{7 6})\end{array}$ & Statistical results \\
\hline Age & $45.69 \pm 10.66$ & $41.12 \pm 10.42$ & $\mathrm{p}=0.19 ; \mathrm{t}=-2.49 ; \mathrm{df}=132$ \\
$\begin{array}{l}\text { Gender } \\
\text { male }\end{array}$ & 13 & 12 & \\
$\quad$ female & 45 & 64 & \\
Height $(\mathrm{cm})$ & $166.53 \pm 7.94$ & $167.80 \pm 8.88$ & $\mathrm{p}=0.39 ; \mathrm{t}=0.56 ; \mathrm{df}=132 ;$ \\
Weight $(\mathrm{kg})$ & $69.07 \pm 14.50$ & $67.79 \pm 13.62$ & $\mathrm{p}=0.60 ; \mathrm{t}=-0.52 ; \mathrm{df}=132$ \\
BMI & $24.89 \pm 5.01$ & $24.04 \pm 4.28$ & $\mathrm{p}=0.29 ; \mathrm{t}=-1.06 ; \mathrm{df}=132$ \\
\hline
\end{tabular}

$\mathrm{p}$ - level of significance; $\mathrm{t}$ - Student's coefficient; $\mathrm{df}$ - degree of freedom. 
combination of depressive mood and psychomotor over-activation multiplies the suicidal risk.

So, early detection of subthreshold bipolarity in unipolar depression would lead not only to the correct treatment with mood stabilizers and/or antipsychotics, but also would help to take more effective measures for prevention of suicidal behavior. ${ }^{17-20}$ We expected that the study of psychomotor disturbances through quantitative measurement and objective recording of stepping locomotion (differentiating between psychomotor activity and reactivity) would detect a latent bipolarity in a proportion of patients presented clinically with unipolar depression.

\section{MATERIAL AND METHODS}

\section{PARTICIPANTS}

A group of 58 unipolar depressed inpatients was examined and compared to 76 matched healthy controls (Table 1). All participants signed informed consent forms. Excluded from the sample were patients with clinical evidence of orthopedic, neurological and endocrine diseases, head injuries, substance abuse and comorbidity with other psychiatric disorders as well as patients with clinical features of sedation and/or extrapyramidal symptoms.

\section{Clinical evaluation and assessments}

All patients met the ICD-10 diagnostic criteria for recurrent depressive disorder. Our unipolar depressive patients and healthy controls were age, height, weight and BMI matched (Table 1).

INSTRUMENTAL ASSESSMENT OF THE PSYCHOMOTOR FUNCTION

Emotional disturbances are closely related to disturbances in motility (including locomotion), which is supported by the fact that the origin of the word "emotion" comes from the Latin verb for movement - „movere”. The strong correlation between emotion and locomotion is often reflected in everyday language. In English for example, we speak of "spring in one's step" when someone is in a bright mood and of "heavy steps" when someone is in a sad mood.

Having in mind these relations between emotion and locomotion our team used computerized ultrasonographic cranio-corpo-graphy (www.zebris. de) in order to monitor psychomotor disturbances in depressive patients. This is a non-invasive method for objective recording and measurement of the head and body movements during the performance of motor and equilibriometric tests. It was intro-

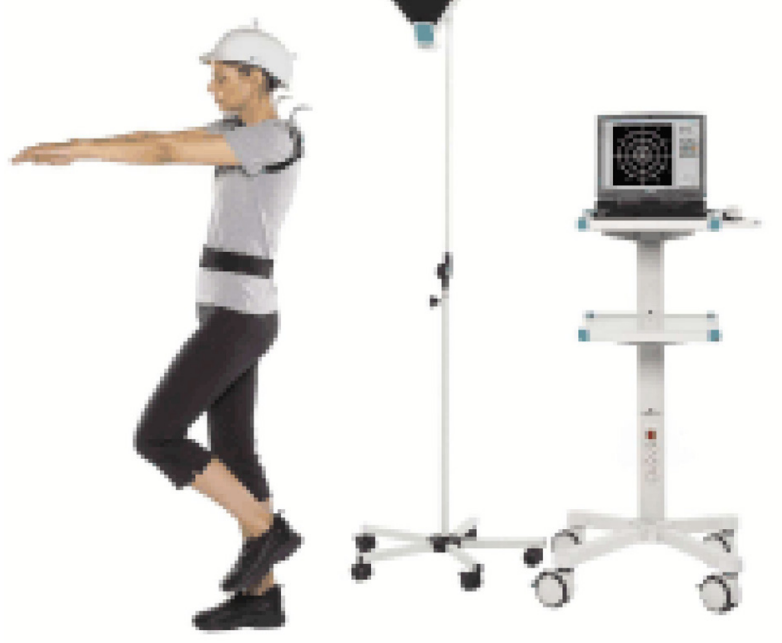

Figure 1. Computerized ultrasonographic cranio-corpography - Test of Unterberger-Fukuda.

duced in psychiatric practice by our team. ${ }^{21-26}$ The participants performed the locomotor "stepping test" of Unterberger-Fukuda (Fig. 1). They stepped in place with outstretched hands and closed eyes for 1 minute.

\section{CRANIO-CORPO-GRAPHIC INDICATORS}

Our studies have found that this equilibriometric test allows a precise subclinical measurement of two basic components of psychomotor performance: conscious (volitional) activity and unconscious (automatic) reactivity. ${ }^{21,25}$ Psychomotor activity is measured by the indicator "number of steps per minute", which directly reflects the speed of locomotion and is determined by the internal rate of spontaneous mental activity. If it is lower than the normal values, it can be regarded as a manifestation of reduced (inhibited) psychomotor activity or hypo-activity. Conversely, if it is higher than the normal values, it can be regarded as a manifestation of increased (disinhibited) psychomotor activity or hyper-activity. Psychomotor reactivity is measured by the indicator "lateral sway". If it is higher than the normal values, it can be regarded as a delay (retardation) in psychomotor reactivity (brady-reactivity). Conversely, if it is lower than the normal values, it can be regarded as acceleration of psychomotor reactivity (tachy-reactivity). It is worth noting that prototypical depressive pattern involves higher values of lateral sway (brady-reactivity) but lower values of number of steps per minute (hypo-activity). In contrast, prototypical manic pattern involves lower values of lateral sway (tachy-reactivity) but higher 
Table 2. Psychomotor subgroups

\begin{tabular}{lccccc}
\hline $\begin{array}{c}\text { Subgroups } \\
\text { Unipolar patients }\end{array}$ & Hyporeactive & Hyperreactive & Total & Hyperactive & Hypoactive \\
\hline Number $(\%)$ & $38(65.5 \%)$ & $20(34.5 \%)$ & $58(100 \%)$ & $25(43.1 \%)$ & $33(56.9 \%)$ \\
\hline Lateral sway $(\mathrm{cm})$ & $17.66 \pm 4.37$ & $10.14 \pm 1.26$ & $12.11 \pm 3.14$ & $12.50 \pm 2.97$ & $17.01 \pm 5.51$ \\
\hline Number of steps per minute & $64.45 \pm 16.73$ & $76.59 \pm 17.57$ & $71.38 \pm 13.20$ & $84.78 \pm 11.01$ & $56.41 \pm 10.89$ \\
\hline
\end{tabular}

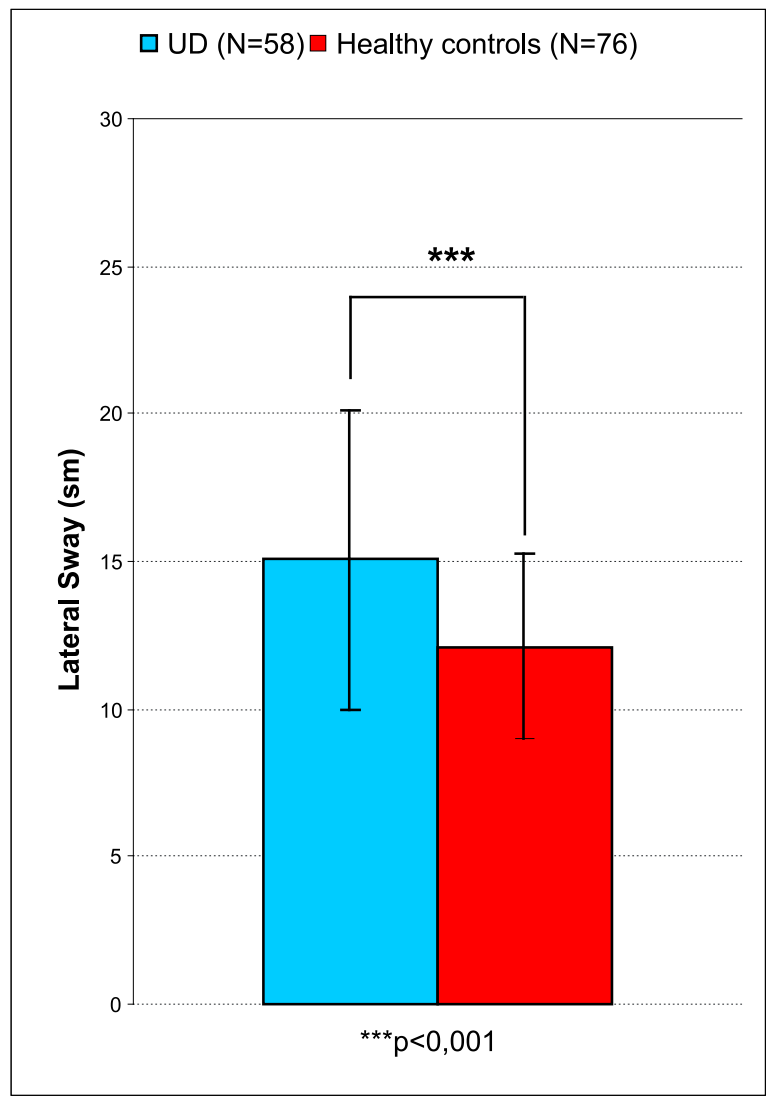

Figure 2. Statistically significant differences between healthy controls and patients with UPD in CCG-indicator "lateral sway".

values of number of steps per minute (hyper-activity).

\section{RESULTS AND DISCUSSION}

Compared to controls, patients with unipolar depression were significantly slowed down only in their reactivity, but not in their activity (Figs 2, 3).

We subdivided the whole group of unipolar patients into two pairs of separate subclinical subgroups according to their psychomotor activity and reactivity compared to the mean values of the control group. Therefore, using the two opposite deviations from the norm for both psychomotor indicators we formed the subclinical subgroups of hyper- vs. hypo-reactive and hyper- vs. hypo-active

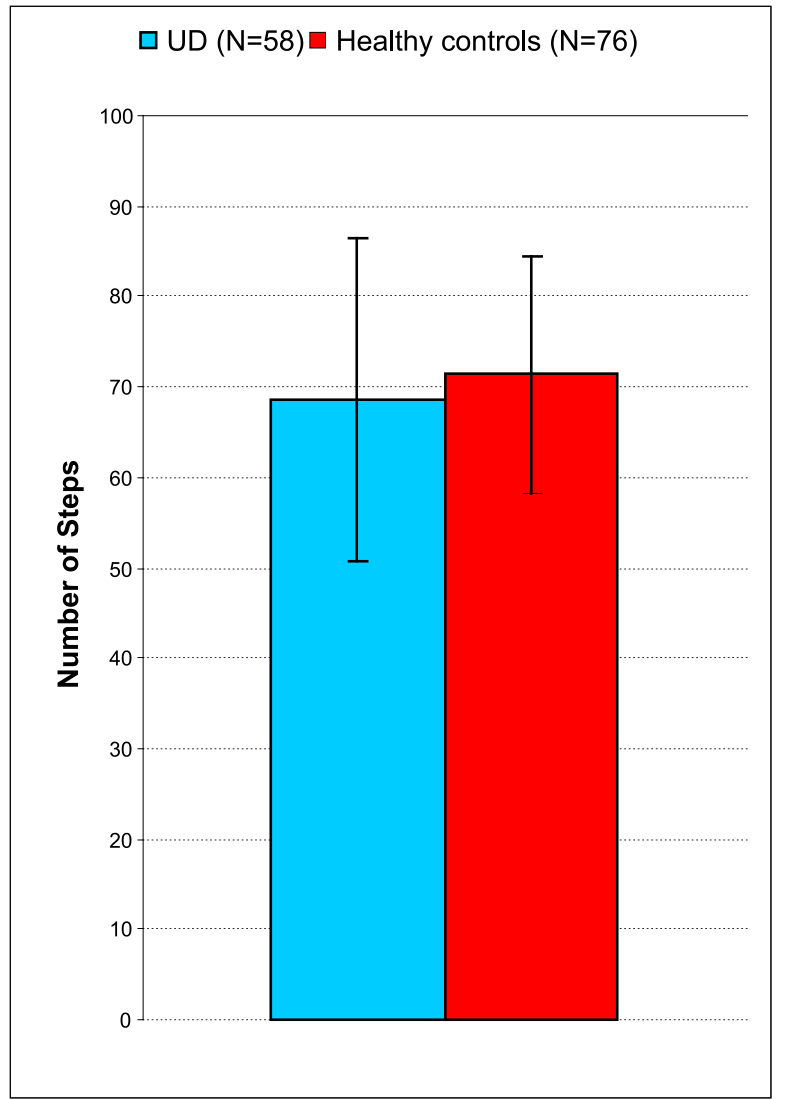

Figure 3. Statistically significant differences between healthy controls and patients with UPD in CCG-indicator "number of steps".

unipolar patients (Table 2).

These findings suggested that the group of unipolar patients was a heterogeneous one. The hyper-reactive patients were statistically significantly speeded up in their reactivity compared to the healthy controls and logically compared to the subgroup of hypo-reactive patients. The subgroup of hyper-reactive patients presented with preserved psychomotor activity and its measured value was even higher than that of the norm (Figs 4, 5).

Approximately only a half of our unipolar patients were slowed down in their psychomotor activity. Surprisingly, the other half were with psychomotor hyper-activity, meaning that their cranio-corpo- 


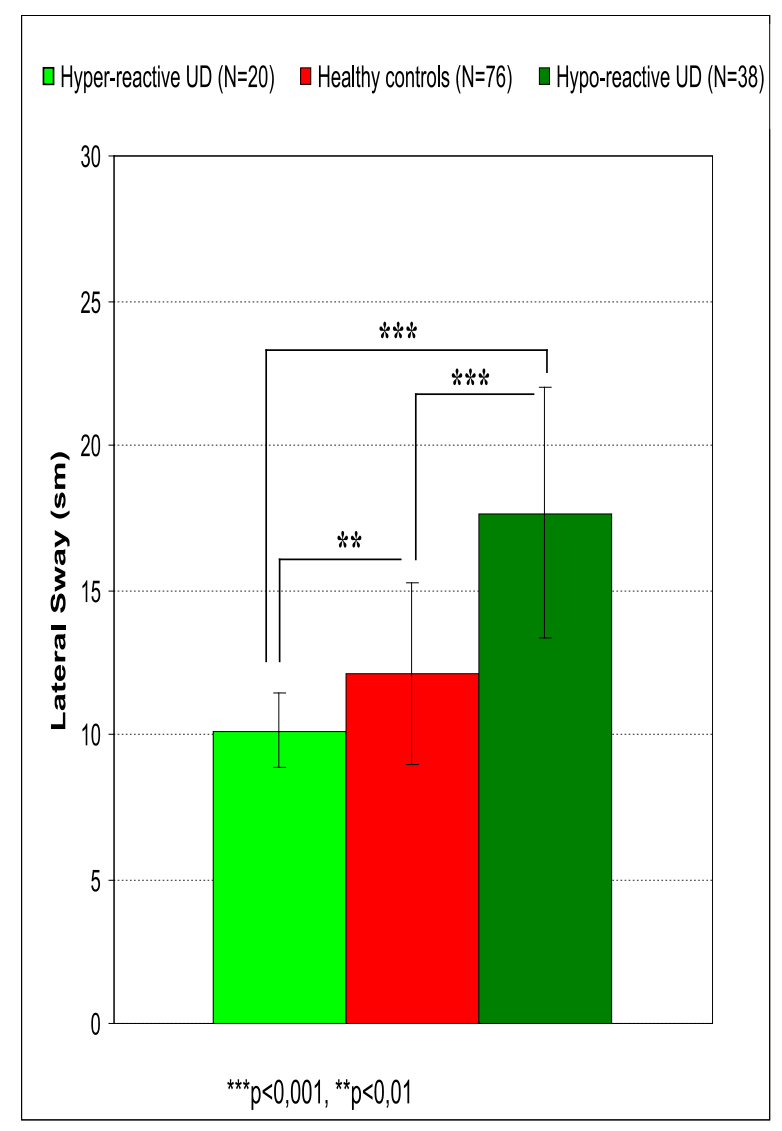

Figure 4. Statistically significant differences between healthy controls, hyper-reactive and hypo-reactive patients with UD in CCG-indicator "lateral sway".

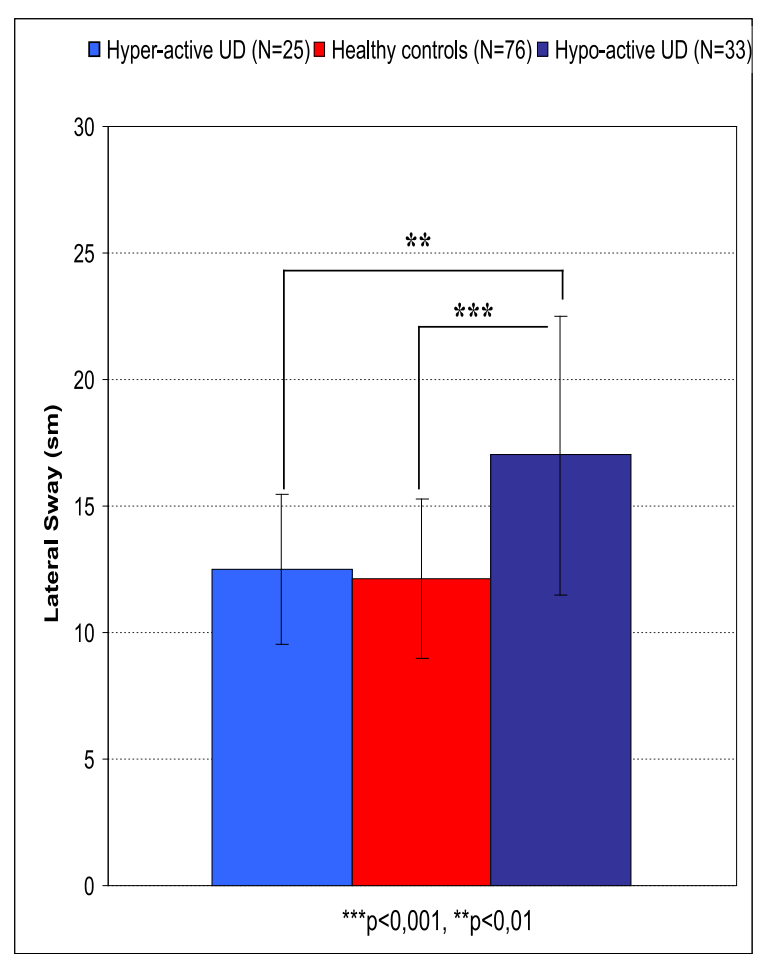

Figure 6. Statistically significant differences between healthy controls, hyper-active and hypo-active patients with UPD in CCG-indicator "lateral sway".



Figure 5. Statistically significant differences between healthy controls, hyper-reactive and hypo-reactive patients with UD in CCG-indicator "number of steps".

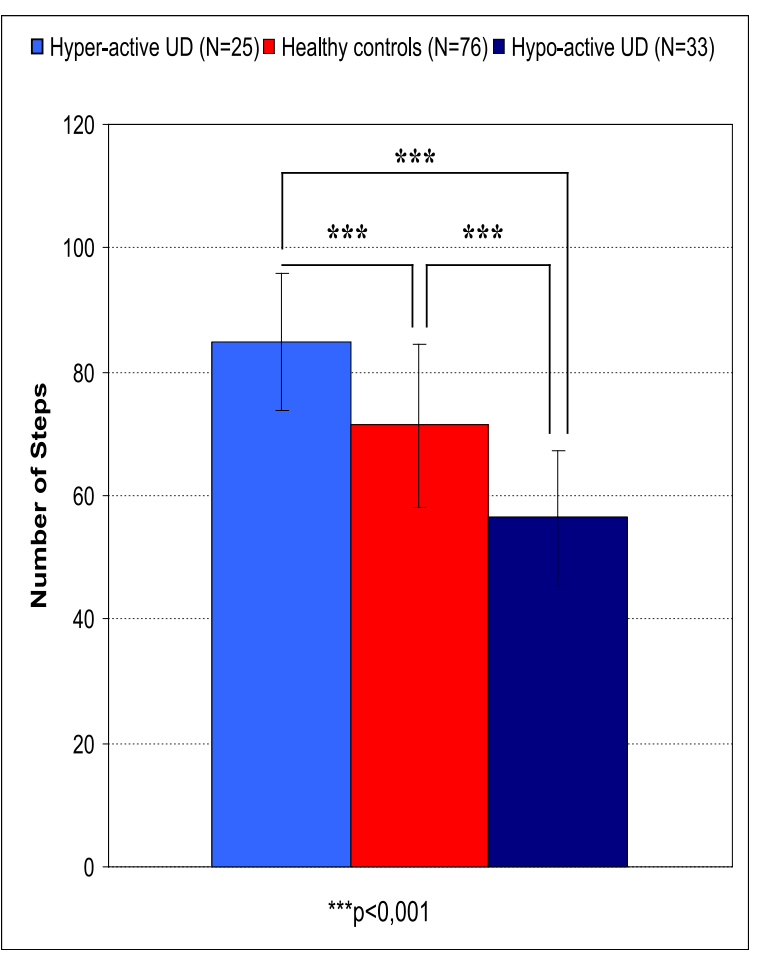

Figure 7. Statistically significant differences between healthy controls, hyper-active and hypo-active patients with UPD in CCG-indicator "number of steps". 
graphic movement patterns reveal some elements specific for patients with mania and hypomania (Figs 6, 7).

We could consider the measured acceleration in reactivity and activity in our hyper-reactive and hyper-active unipolar patients as a subclinical presentation of an underlying mixed state. ${ }^{14,27}$

We considered the combination of depressive mood with mania-like psychomotor hyper-reactivity and hyper-activity as a sign of latent bipolarity and checked these subgroups of unipolar depressive patients for other known features of latent bipolarity. ${ }^{8,9}$ As we know the early onset of the first affective episode is considered to be a marker of bipolarity ${ }^{6,28}$ and in our group hyper-active unipolar patients did not differ from bipolar patients in their age of onset $(\mathrm{p}>0.05)$.

We estimated that in $85.7 \%$ of our hyper-reactive unipolar patients no full remission was observed during the last 3 years. We defined a full remission as 8-week-long asymptomatic period of time for the depressive patients. ${ }^{1,29}$ Many authors considered residual depressive symptoms and tendency to chronicity of the depression as clinical presentation of latent bipolarity usually due to poor medical treatment. ${ }^{5,6,12,30,31}$

"Racing thoughts" as a psychopathological phenomenon was observed in $76.9 \%$ of our hyper-active unipolar patients. They revealed at the clinical interview that they have "racing thoughts" during the present depressive episode.

Latent bipolarity leads also to increase of suicidal risk. ${ }^{15,16}$ In unipolar patients the combination of hypo-reactivity with hyper-activity could facilitate the suicidal attempts. Objective registration of hyper-activity in unipolar patients could be used for suicidal prevention as well as for proper treatment of the patients. ${ }^{9}$ Our hyper-reactive unipolar patients were supposed to be at higher risk for suicide as they had a family history for relatives who committed suicide. The family history was statistically significant (Fisher's exact test, $\mathrm{p}=0.016$ ). Early detection of hyper-reactivity and hyper-activity could be used for prevention of suicidal attempts.

It is considered that latent bipolarity leads to poor treatment outcomes and underlies treatment-resistant depressions. ${ }^{32}$ The acceleration in psychomotor activity and reactivity registered by cranio-corpography could be used for more adequate choice of medication. The observed combination of depressive mood and psychomotor hyper-reactivity or hyperactivity could help clinicians to avoid monotherapy with antidepressants and to use mood stabilizers and/or atypical antipsychotics instead.

\section{CONCLUSIONS}

Cranio-corpo-graphy could be applied for objective and quantitative recording of psychomotor disturbances in endogenous depression. As a result, we revealed that the group of unipolar depressive patients is heterogeneous at a subclinical psychomotor level. Cranio-corpo-graphically recorded increased psychomotor activity and/or reactivity in these patients could be regarded as a neurobehavioral marker of latent bipolarity and should be treated as a manifestation of subclinical mixed state. Accordingly, the more adequate treatment of thus revealed latent psychomotor hyper-activity and tachy-reactivity could improve both clinical outcome and suicidal prevention in clinically manifested unipolar depression.

\section{REFERENCES}

1. Keller MB, Lavori PhW, Mueller TI, Endicott J, Coryell W, Hirschfeld RM, et al. Time to recovery, chronicity, and levels of psychopathology in major depression: a 5-year prospective follow-up of 431 subjects. Arch of Gen Psychiatry 1992;49(10):809-16.

2. Ayuso-Mateos JL, Vazquez-Barquero JL, Dowrick C, Lehtinen V, Dalgard OS, Casey P, et al. Depressive disorders in Europe: prevalence figures from the ODIN study. Br J Psychiatry 2001;179:308-16.

3. Lopez AD, Mathers CD, Ezzati M, Jamison DT, Murray CJL. Global and regional burden of disease and risk factors, 2001: systematic analysis of population health data. The Lancet 2006;367(9524):1747-57.

4. Sobin C, Sackeim HA. Psychomotor symptoms of depression. Am J Psychiatry 1997;154(1):4-17.

5. Mitchell PB, Malhi GS. Bipolar depression: phenomenological overview and clinical characteristics. Bipolar Disord 2004;6(6):530-9.

6. Mitchell PB, Goodwin GM, Johnson GF, Hirschfeld RMA. Diagnostic guidelines for bipolar depression: a probabilistic approach. Bipolar Disord 2008;10(12):144-52.

7. Parker G. Classifying clinical depression: an operational proposal. Acta Psychiatr Scand 2011;123(4): 314-16.

8. Haralanov S, Terziivanova P. Subclinical psychomotor heterogeneity in unipolar and bipolar depression: objective evaluation by computerized ultrasonographic cranio-corpography. Bulg Neurol Psychiatr Practice 2010;(3-4):22-31.

9. Haralanov S, Terziivanova P. Subclinical bipolarity in unipolar depression: objective revealing by computerized ultrasonographic cranio-corpo-graphy. 
Bulgarian Medicine 2011;1(3-4):14-25.

10. Terziivanova $\mathrm{P}$, Haralanov S. Psychomotor retardation and agitation in clinical depression. In: Stoyanov, D (editor) Psychopathology: Theory, Perspectives and Future Approaches. New York: Nova Science Publishers; 2013:283-298.

11. Marneros A, Goodwin FK. Bipolar disorders beyond major depression and euphoric mania. In: Bipolar disorders: mixed states, rapid cycling and atypical forms. Marneros A, Goodwin FK, editors. Cambridge University Press; 2005:1-37.

12. Akiskal HS, Benazzi F, Perugi G, Rihmer Z. Agitated "unipolar" depression re-conceptualized as a depressive mixed state: implications for the antidepressant-suicide controversy. J Affect Disord 2005;85(3)245-58.

13. Hantouche EG, Akiskal HS, Lancrenon S, ChatenetDuchene L. Mood stabilizer augmentation in apparently "unipolar" MDD: predictors of response in the naturalistic French national EPIDEM study. J Affect Disord 2005;84(2):243-9.

14.Koukopoulos A, Albert MJ, Sani G, Koukopoulos AE, Girardi P. Mixed depressive states: nosologic and therapeutic issues. Intl Rev Psychiatry 2005:17(1):21-37.

15.Stang PE, Frank C, Kalsekar A, Yood MU, Wells K, Burch S. The clinical history and costs associated with delayed diagnosis of bipolar disorder. Med Gen Med 2006;8(2):18.

16. Hirschfeld RM, Lewis L, Vornik LA. Perceptions and impact of bipolar disorder: how far have we really come? Results of the National Depressive and Manic-depressive Association 2000 survey of individuals with bipolar disorder. J Clin Psychiatry 2003;64(2):161-74.

17. Anderson IM. Meta-analytical studies on new antidepressants. Br Med Bull 2001;57(1):161-78.

18. Anderson IM, Ferrier IN, Baldwin RC, Cowen PJ, Howard L, Lewis G, et al. Evidence-based guidelines for treating depressive disorders with antidepressants: a revision of the 2000 British association for psychopharmacology guidelines. J Psychopharmacol 2008;22(4):343-96.

19. Baldessarini RJ, Pompili M, Tondo L, Tsapakis E, Soldani F, Faedda GL, et al. Antidepressants and suicidal behavior: are we hurting or helping? Clin Neuropsychiatry 2005;2(1):73-5.

20. Fawcett J A, Baldessarini RJ, Coryell WH, Silverman
MM, Stein DJ. Defining and managing suicide risk in patients taking psychotropic medications. J Clin Psychiatry 2009;70(6):782-9.

21. Claussen CF, Haralanov S. Method for evaluating a movement pattern. United States Patent $6,473,717 / 2002$.

22. Haralanov S, Claussen CF, Shkodrova D, Haralanov L, Schneider D, Carvalho C. Cranio-corpography in schizophrenic patients. In: Claussen CF, Sakata E, Itoh A, editors. Vertigo, Nausea, Tinnitus and Hearing Loss in Central and Peripheral Vestibular Diseases. Amsterdam-New York-Oxford-Tokyo: Elsevier; 1995:325-8.

23. Haralanov S, Claussen CF, Schneider D, Haralanov L, Carvalho C, Stamenov B. Cranio-corpography: implications and perspectives in the field of clinical equilibriometry. Neurologia Balkanica 1997;1:30-4.

24. Haralanov S, Milushev E, Claussen CF. Neuromotor and psychomotor dysfunctions in schizophrenic patients: objective recording and quantitative evaluation by computerized ultrasonic cranio-corpography. Bulgarian Neurology 2001;1(2):55-6.

25.Haralanov S, Claussen CF, Haralanova E, Shkodrova D. Computerized ultrasonographic craniocorpography and abnormal psychomotor activity in psychiatric patients. International Tinnitus Journal 2002;8(2):72-6.

26. Haralanov S, Shkodrova D, Claussen CF. Craniocorpo-graphic findings in schizophrenic patients. Neurootology Newsletter 2002;6(1):27-31

27.Koukopoulos A, Koukopoulos A. Agitated depression as a mixed state and the problem of melancholia. Psychiatr Clin North Am 1999;22(3):547- 64.

28. Akiskal HA. Classification, diagnosis and boundaries of bipolar disorders: A review. In: Maj M, Akiskal H, Ibor-Lopez JJ, Sartorius N, editors. Bipolar Disorder. WPA Series Evidence and Experience in Psychiatry (5). John Wiley \& Sons; 2002:9.

29. Mondimore FM, Zandi PP, MacKinnon DF, McInnis MG, Miller EB, Crowe RP, et al. Familial aggregation of illness chronicity in recurrent, earlyonset major depression pedigrees. Am J Psychiatry 2006;163(9): 554-60.

30.Benazzi F. Agitated depression: a valid depression subtype? Prog Neuro-Psychoparmacol Biol Psychiatry 2004;28(8):1279-85. 